\title{
Creating a Developmentally Appropriate Learning Environment in Preschool Education Institutions
}

\author{
Reipolska Olga \\ ORSID ID 0000-0002-5524-7110 \\ PhD in Pedagogy, Associate Professor \\ Institute of Problems on Education \\ of the National Academy of Educational Sciences of Ukraine (Kyiv, Ukraine) \\ Lutsenko Victoriia \\ ORSID ID 0000-0002-1681-0601 \\ Research Officer \\ Institute of Problems on Education \\ of the National Academy of Educational Sciences of Ukraine (Kyiv, Ukraine)
}

\begin{abstract}
The article is devoted to the problem of modernization of preschool education in the conditions of modern educational reforms related to realization of humanistic paradigm. The authors describe the creating of developmental educational environment in establishments of preschool education.

The article presents the theoretical substantiation and some technological statements of designing the educational environment as a factor in the development of the personality of a preschool child, in particular, theoretical and methodological principles of designing the educational environment of preschool education, namely: principles (pedagogical expediency, integrity, individualization, cognitive activity and independence), basic scientific approaches (systemic, synergetic, environmental, personality-oriented, activity-communicative), objective laws.

The authors found that the theoretical interpretation of the concept the preschool child's personality development is based on the scientific position on its integrity and ability to make qualitative changes in the process of their own activities and communication with other people. It is determined that the development of the child's personality directly depends on the quality of content and procedural organization of the environment in which he is brought up.

Key words: educational environment, developmentally appropriate learning environment, preschool education institutions, personal development, preschool child.
\end{abstract}

Relevance of the research. Modernization processes have caused significant changes in the domestic preschool education system. The implementation of the humanistic paradigm actualized the concept of an educational environment, which was little in demand in previous times because in fact it was almost replaced by the concept of the educational process.

The problem of creating a developmental environment and organization of educational work in it is due to the fact that the vast majority of teachers, unfortunately, reduces the concept of "educational environment" to the subject-spatial organization of furniture, equipment, 
teaching aids in the group, ignoring other aspects of this phenomenon, in particular, the possibility of personal self-determination of the preschooler in various activities, despite the imposition on him of activities organized at the initiative of the teacher.

The purpose of the research is to present the results of the ascertaining stage of the pedagogical experiment on the creation of a developmental educational environment for the individual development of the child.

Review of previous studies. The theoretical basis of the problem of creating an educational environment in the school as a means of personal development of children of early and preschool age is the scientific achievements of scientists, performed within the issues of the philosophical and sociological concept of personality culture (Kagan [5]); psychological theory of personality (Leontiev [11]; Rubinstein [17]); personality development in preschool age (Artemova [1], Elkonin [20], Kononko [9], Ladivir [19], Pirozhenko [15]; personalityoriented approaches to personality development (Bekh [2], Yakymenska [21]; modernization of the preschool education system (Gavrish [4], Kononko [9], Ponimanska [16], etc.); transformation of the educational space of the preschool institution (Kononko [9], Krutiy [4], Matviienko O. [22; 23], Pet'ko [12; 13; 14], and others).

Findings and discussions. Research work is carried out on the basis of preschool institutions of Ukraine in 5 regions: Kyiv, Donetsk, Rivne, Khmelnytsky, and Chernivtsi. The program of research work provided for the study of the features of the educational environment created by teachers and the forms of organization of educational work with children in it.

During the research, educators of early age groups and preschool groups recorded and sent in the form of photographs, videos, descriptions of the structural and semantic content of the educational environment of groups, accompanied by comments explaining their vision and understanding of each of its elements. In addition, the method of monitoring the independent activities of children in their free time was used. The analysis of the collected information material made it possible to systematize the idea of the state of the subject-content content of the educational environment and the state of individual and differentiated educational work in it.

Generalization of various approaches to the definition allows us to conclude that the developmental educational environment of a modern educational institution - a set of spiritual and material conditions of the educational institution, ensuring self-development of free and 
active personality, the realization of the creative potential of the child. The developmental educational environment is a functional and spatial association of subjects of education, between which close diverse relationships are established, and can be considered as a model of socio-cultural space, where the formation of personality takes place.

The organization of the educational development environment is defined as the provision of a set of conditions related to the logistical and software-methodological support of the educational process; creation of conditions of creative comfortable interaction of children among themselves, with teachers, parents; using various methods and means of activating activities that ensure the creative development of the individual, etc. $[6 ; 7 ; 12 ; 13$; $14 ; 18 ; 21 ; 22]$.

Under the developmental educational environment we understand specially modeled conditions (natural, subject and social) in which the child grows, masters the science of life, becomes a competent person with its own individual characteristics. Creating an educational environment allows the child to realize their own potential, take the initiative and fully realize themselves.

The main idea of the study is to understand the relationship between the development of the personality of a preschool child and the developmental educational environment organized by teachers in a preschool institution conducive to child development.

Theoretical analysis of philosophical, psychological, pedagogical literature allowed to determine the essence of the conceptual phrase "designing the educational environment" as a specially organized pedagogical activity, which consists in building and implementing a system of scientific guidelines that set the technological vector of interaction of all participants (subjects). aimed at the holistic development of the child's personality.

During the implementation of the ascertaining stage of the pedagogical experiment, our attention was focused on: identifying the level of understanding by teachers of the conceptual field of research; content and procedural content of the educational environment in the groups of early age and preschool groups of basic PEI (preschool education institutions); features of organized by adults and independent activities of children in the educational environment of groups.

It was found that at the beginning of the study, most teachers $(67,8 \%$ of respondents) have somewhat misguided, outdated ideas about the nature, functions and structure of the 
educational environment. Thus, the educational environment is considered by them as a closed social construct, which should be dominated by the subject-object interaction of the teacher with the child, as a result, preference is given to authoritarian ways of interacting with children in the model "top-down", and personality development is seen as one-sided learning process, transfer of knowledge-skills-abilities available to the child by the teacher.

The share of progressive educators (32,2\% of respondents) have a positive attitude to the idea of free self-determination of children in the subject-spatial environment of the group (which significantly narrows the essence of the concept), but only 5,7\% have the opportunity to do so. The presence of the so-called "network of classes", according to $48,7 \%$ of respondents, does not leave time for active and proactive activities of children in the group. In addition, most of the educators surveyed ( $74 \%$ ) even outside the classroom try to organize children around them, minimize free space for independent activity, fearing to lose control over children ("If I let them (children), how can I collect", "I then I will not be able to see / control everyone" - typical answers of teachers).

The analysis of the obtained data convincingly shows that the educational environment is not considered (67\%) and is not used (87\% of respondents) as a factor in the development of the child's personality. Neither educators nor the management of experimental children have a clear idea of the place and facilitation role of the teacher in stimulating different types of children's activity, to some extent they are afraid of it, because they have no experience of competent psychological and pedagogical support of children's personal development.

Note that nominatively in the vast majority of groups of both early and preschool age (87\%) for the development of developmental centers and active activities of children in them: play, sensory, book, art center, intellectual, physical development, theater, and so on. The $46 \%$ of groups are dominated by modern play and didactic equipment, but $54 \%$ have a filling of educational centers that do not meet the age, needs and interests of modern children. A special problem is the lack of sufficient space and overcrowding of groups, which does not allow children to develop activities of their choice, they do not have the opportunity to be alone or self-determined with the type or method of their own activities (53\% of respondents noted this).

Problematic, in our opinion, is the fact that the leadership of most PEI does not consider the educational activities of teachers outside the classroom, in an individual format, as 
valuable, important, and therefore requires teachers to constantly orient children on their own, their constant association for group, orderly activities in which, in their opinion, the activities of the educator is obvious. The uniformity of the general group form of organization of children for moving play, observation, reading, explanation, etc. does not take into account the interest and desire of a particular child. Therefore, the vast majority of children perceive the explanations, demonstrations, actions of the educator without enthusiasm, at the first opportunity try to get away, do not hold attention. That is, the result of such educational work is minimal.

The survey of educators showed that in $95 \%$ of cases teachers are not ready to implement the principle of individualization and differentiation of educational activities in the developmental environment of the group. They are lost in the development of tasks for individual work, can not determine the real level of complexity required by a particular child, because methodically competent to observe the actions of children, reflect and reflect, unfortunately, are not trained.

Thus, the results of the observational experiment, their analysis and reflection served as a platform for determining favorable psychological and pedagogical conditions for personal development of preschool children in the educational environment of preschool education and development of experimental methods of relevant educational work on the basis of individualization and differentiation.

The development of the environmental model was based on the idea of a holistic approach to organizing their lives in preschool education, updating the content, forms and methods of educational activities, creating a developmental environment that will promote the use of personality-oriented technology in early ontogenesis of socially approved patterns of behavior (Manuilov, 2008).

The implementation of the concept was aimed at enriching preschoolers' ideas about their own virtues and flaws; fostering in them self-esteem, the ability to trust their own abilities; formation of the ability to behave independently, to act constructively, to defend one's own dignity in one's actions and deeds, to substantiate one's own opinion, to focus on basic moral values. An important direction was to ensure the balance of self-physical, self-spiritual and self-social available to preschoolers, optimization of the model of interaction in the systems 
"adult-child" and "child-child"; creation of appropriate theoretical and methodological and software.

Let's briefly reveal our own understanding of the main positions of building an educational environment on the declared values set out above.

In the educational process there is a correlation of three main models of interaction between teacher and children: "learning by example" (educator dominates over children), "joint activities" (parity) and "independent activities of children" (activities that occur at the initiative of children), and in favor of the first model.

To the block "We teach by example" we include all situations when the educator dominates (shows the initiative, proclaims, informs, directs actions of children, organizing them). With the dominance of the first model, it is obvious how important for the teacher what he plans, he says, he will do himself, and how insignificant time is for the child's own initiatives. In situations of the second model "Joint activity" (joint play, communication, research, work), the adult also tries to maintain a dominant position. However, scientists have long proven that the child develops best in activities in which he takes an active position, and not just a listener and performer; that she will assimilate the information she aspired to most fully and qualitatively, and not the information that should be according to the plan. As for the third model, independent does not mean thoughtless, aimless activity of children, it is an activity in which the child, showing interest in what he is doing, makes his own efforts to realize his plans.

Changing the ratio of these models in favor of the dominance of independent activity is the main condition for shifting the emphasis to educational work in the developmental educational environment. This in no way means abandoning the classroom as a form of learning, it must acquire modern characteristics corresponding to the declared humanistic idea.

When planning educational work in the educational environment, we should focus not so much on the knowledge component, but on the child's mastery of the main types of children's activities - play, speech, communication, sensory-cognitive, artistic-aesthetic, household, health. There can be several options. First: abandon daily planning; reorient to drawing up a plan for the week; to determine in the weekly planning a specific goal-result - "after living with children... they will be able to". The second option - planning educational work by type of activity, taking into account the three blocks identified by us: what new knowledge and 
skills I want to teach children; in what knowledge-skills to exercise by means of joint activity; favorable conditions must be created for mastering any independent actions. The third option: to the traditional way of planning to add a block of tasks focused on their implementation in terms of independent activity.

Group-wide integrated classes should be held daily. However, in the daily life of children, we must free up time for independent activities in a thoroughly prepared, filled with the necessary materials environment. When we talk about independent activities, we mean free play of children and independent cognitive, artistic, physical activity in a group or on the playground. In order for children's activities to be useful and interesting for them, the educator should fill the environment with the materials necessary for independent activity and place the centers in a group room so that children do not interfere with each other.

During independent activities for all or most children, the educator can conduct individual (from one to 3-4 children) educational work, keeping all other children in sight. Expanding the limits of freedom for children - the teacher must agree with the children on the rules and strictly follow them. There should be a limited number of rules, for example 2-4. They should be formulated concisely and be sure to choose a symbolic symbol or signal word for each child. Another issue concerns the self-organization of children. Today, there are many different proven ways to help children organize themselves in a group environment for independent activity. Thus, the use of a socio-game method (by the color of ribbons, rubber bands, the size of buttons, etc.) helps children to determine by lot what activities they want to do. The time management screen works successfully for this purpose in separate kindergartens.

The smallest but very important unit of organization of educational work in the developmental environment of the group is the task. It is with the help of tasks that the educator can direct the independent cognitive or artistic activities of children. In order to perform the task correctly, the child must understand what he has to do. It is necessary to develop tasks for children so that each corresponds to a specific educational task, has clear and understandable for the child criteria for the quality of its implementation. Given the different levels of preparation and development of children, the tasks should be differentiated by complexity, have a reproductive (do exactly as in the picture) or creative nature of the performance (consider how you could do it). 
Tasks should be offered to children in a planned way, with a gradual complication of the content, so that it can be provided through their implementation of the educational program. Each of the children in the group must complete the required tasks during the day or week. If the task did not work out the first time, the child should be able to practice to achieve the desired result. In addition to the required ones, the educator should prepare a sufficient number of other tasks that the children will perform in their free time. Children can celebrate their achievements (I have learned, I already know how to...) on a special ribbon of achievements and desires. The child sets a task to learn something "I want", and then notes that now she has learned "I can". It helps children develop such important skills as goal setting and develop an equally important quality as focus.

Conclusions. The article presents the theoretical justification and some technological statements of designing the educational environment as a factor in the development of the personality of a preschool child, in particular, theoretical and methodological principles of designing the educational environment of preschool education, namely: principles (pedagogical expediency, integrity, individualization, cognitive activity and independence), basic scientific approaches (systemic, synergetic, environmental, personality-oriented, activity-communicative), objective laws. It is established that the basis of the theoretical interpretation of the concept of personality development of a preschool child is the scientific position on its integrity and ability to make qualitative changes in the process of their own activities and communication with other people. It is determined that the development of the child's personality directly depends on the quality of content and procedural organization of the environment in which he is brought up.

The research continues, further publications will cover the criteria and indicators, types of individual personal development of older preschool children, reveal the conditions of

designing an educational environment for individual personal development of early and preschool children, characterize the model of designing an educational environment.

\section{References}

1. Artemova L. Realiyi ta perspektivi rozvitku doshkIlnoYi osvIti Ukrayini v kontekstI klyuchovih pozitsIy Bolonskoyi deklaratsiyi [Realities and prospects of preschool education development in Ukraine in the context of key positions of the Bologna Declaration]. Visnik GluhIvskogo derzhavnogo natsIonalnogo pedagogIchnogo universitetu im. O. Dovzhenka. 2010. Vol 16. Pp. 10-14. 
2. Bekh I. D. Osobystist u konteksti oriientyriv rozvyvalnoho vykhovannia [Personality in the context of guidelines for developmental education]. Innovatyka u vykhovanni. 2015. URI : http://nbuv.gov.ua/UJRN/inuv2015_1_4

3. Vyhotskyi L. S. Psykholohyia razvytyia cheloveka [Human developmental psychology]. Moskva : Smysl; Eksmo, 2005.

4. Gavrish N., Krutiy K. Seredovischna model-panatseya? Lamaemo stereotipi [Is the environmental model a panacea? We break stereotypes.]. DoshkIlne vihovannya. 2019. No 4. Pp. 4-11.

5. Kagan M. Sistemnyiy podhod $i$ gumanitarnoe znanie [Systems approach and humanitarian knowledge] : Izbr.st. M.S.Kagana. Leningrad: izd-vo LGU, 1991.

6. Kanishevska L. V. Krokuiemo do sotsialnoi zrilosti [Stepping towards social maturity] : nauk.-metod. posib. Kyiv: In-t problem vykhovannia NAPN Ukrainy, 2011. 175 p.

7. Kanishevska L. V., Vyshnivska N. V. Pedahohichni umovy vykhovannia humannosti $v$ uchniv molodshoho shkilnoho viku $v$ pozaurochnii diialnosti shkilinternativ [Pedagogical conditions of primary school students' humanity education in extracurricular activities at boarding schools] // Topical issues of pedagogy: Collective monograph. - Edizioni Magi, Roma, Italy, 2019. 228 p.

8. Kanishevska L. V., Sukhopara L. V. Formuvannia tolerantnosti $v$ molodshykh shkoliariv u pozaurochnii diialnosti: teoriia i praktyka [Formation of tolerance in preschool students in extracurricular activities: theory and practice] : monohrafiia. Kyiv : Komprynt, 2017. $405 \mathrm{p}$.

9. Kononko O. L. Psykholohichni osnovy osobystisnoho stanovlennia doshkilnyka (systemnyi pidkhid) [Psychological bases of personal formation of the preschooler (system approach)]. Kyiv : Stylos, 2000.

10. Krutiy K. Osvitniy prostir doshkilnogo navchalnogo zakladu [Educational space of a preschool educational institution]: monografiya: u 2-h ch. Kyiv : OsvIta, 2009.

11. Leontev O. M. Deiatelnost, soznanye, lychnost [Activity, consciousness, personality.]. Moskva : Nauka, 1975.

12. Petko L. V. Derzhavnyi standart pochatkovoi osvity u rakursi formuvannia sotsialnoi aktyvnosti dytyny [State standard of primary education in the perspective of the formation of social activity of the child]. Naukovi zapysky Berdianskoho derzhavnoho pedahohichnoho un-tu. Seriia : Pedahohika : zb. nauk. prats. Berdiansk : BDPU, 2018. Vol. 1. Pp. 92-97.

13. Pet'ko L. V. Osobystist. Socium. Navchal'ne Seredovyshhe [Personality. Socium. Teaching Environment]. Gumanitarnyj visnyk DVNZ «Perejaslav-Hmel'nyc'kyj derzhavnyj pedagogichnyj universytet imeni Grygorija Skovorody»: zbirnyk naukovyh prac. 2014. Vol. 35. Pp. 102-110.

14. Pet'ko L. V. Pidgotovka majbutnih pedagogiv-vyhovateliv do navchannja inozemnoi movy ditej $v$ doshkilnyh osvitnih zakladah [The ways of a process of preparation of future tutors in foreign language teaching of preschool children] / Visnyk Instytutu rozvytku 
dytyny. Vol. 23. Serija: Filosofija, pedagogika, psyhologija: Zbirnyk naukovyh prac. Kyiv : Vyd-vo NPU imeni M.P.Dragomanova, 2012. Pp. 111-115.

15. Pirozhenko T. O. Ihrova diialnist doshkilnyka : navchalno-metodychnyi posibnyk [Preschool play activities]. Kyiv : Heneza, 2013.

16. Ponimanska T. Gotovnist do pedagogichnih innovatsiy u konteksti gumanistichnoyi pedagogiki [Readiness for pedagogical innovations in the context of humanistic pedagogy]. Onovlennya zmistu i metodiv doshkilnoyi osviti v Ukrayini. 1999. Vol. 5. Rivne : RDPI. Pp. 10-15.

17. Rubynshtein S. L. Osnovi obshchei psykholohyy [Fundamentals of general psychology] : v 2-kh t. Moskva : Pedahohyka, 1989.

18. Sliusarenko N., Kulbatska M. Subiekt-subiektnyi pidkhid do orhanizatsii pedahohichnoho protsesu [Subject-subject approach to the organization of the pedagogical process]. Liudynoznavchi studii. Pedahohika. 2015. No 1 (33). Pp. 194-201.

19. Stanovlennia vnutrishnoi kartyny svitu doshkilnyka [Formation of the internal picture of the preschooler's world] : monohrafiia. Kirovohrad : Imeks-LTD, 2012. URI : http://lib.iitta.gov.ua/1604/ 1960.

20. Elkonyn D. B. Detskaia psykholohyia [Child psychology]. Moskva : Pedahohyka,

21. Yakimanskaya I. Razrabotka tehnologii lichnostno orientirovannogo obucheniya [Development of technology for student-centered learning]. Voprosyi psihologii. 1995. No 2. Pp. 37-38.

22. Matviienko O. Pedagogy of partnership in the process of setting new Ukrainian school // Challenges and opportunities of scientific thought development: collection of scientific articles. - GPG Publishing Group, Pretoria, South Africa, 2017. P. 151-156.

23. Matviienko Olena. Theoretical Basics of Preparation of Teachers to Pedagogical Interaction with Children of Various Age. Intellectual Archive. 2014. Volume 5. No. 5 (September). - Toronto : Shiny Word Corp., Canada. Pp. 105-117.

\section{Translation of the Title, Abstract and References to the Author's Language}

\section{УДК 373.2}

Рейпольська Ольга, Луценко Вікторія. Створюсмо розвивальне освітнє середовище у закладах дошкільної освіти.

Стаття присвячена проблемі модернізації дошкільної освіти в умовах сучасних освітніх реформ, пов’язаних із реалізацією гуманістичної парадигми. Це й актуалізувало необхідність створення розвивального освітнього середовища в закладах дошкільної освіти.

У статті представлено теоретичне обгрунтування та окремі технологічні виклади проектування освітнього середовища як чинника розвитку особистості дитини дошкільного віку, зокрема, теоретико-методологічних засад проектування освітнього середовища закладу дошкільної освіти, а саме: принципи (педагогічної доцільності, цілісності, індивідуалізації, пізнавальної активності та самостійності особистості), основні наукові підходи (системний, синергетичний, середовищний, особистісно- 
зорієнтований, діяльнісно-комунікативний), об'єктивні закономірності. Авторами встановлено, що в основі теоретичного тлумачення поняття розвитку особистості дитини дошкільного віку лежить наукове положення щодо ії цілісності й здатності до якісних змін у процесі власної діяльності і спілкування з іншими людьми. Визначено, що розвиток особистості дитини безпосередньо залежить від якості змісту й процесуальної організації середовища, в якому вона виховується.

Ключові слова: освітнє середовище, розвивальне середовище, заклад дошкільної освіти, особистісний розвиток, дитина дошкільного віку.

\section{Лimepamypa}

1. Артемова Л. Реалії та перспективи розвитку дошкільної освіти України в контексті ключових позицій Болонської декларації. Вісник Глухівського державного національного педагогічного університету ім. О. Довженка. 2010. Вип. 16. С. 10-14.

2. Бех І. Д. Особистість у контексті орієнтирів розвивального виховання. Інноватика у вихованні. 2015. URI : http://nbuv.gov.ua/UJRN/inuv2015_1_4

3. Выготский Л. С. Психология развития человека. Москва : Смысл; Эксмо, 2005.

4. Гавриш Н., Крутій К. Середовищна модель - панацея? Ламаємо стереотипи. Дошкільне виховання. 2019. № 4. С. 4-11.

5. Каган М. Системный подход и гуманитарное знание: Избр.ст. М. С. Кагана. Ленинград: изд-во ЛГУ, 1991.

6. Канішевська Л. В. Крокуємо до соціальної зрілості : наук.-метод. посіб. Київ : Ін-т проблем виховання НАПН України, 2011. 175 с.

7. Канішевська Л. В., Вишнівська Н. В. Педагогічні умови виховання гуманності в учнів молодшого шкільного віку в позаурочній діяльності шкіл-інтернатів // Topical issues of pedagogy: Collective monograph. - Edizioni Magi, Roma, Italy, 2019. 228 p.

8. Канішевська Л. В., Сухопара Л.В.Формування толерантності в молодших школярів у позаурочній діяльності: теорія і практика: монографія. Київ : Компринт, 2017. $405 \mathrm{c}$.

9. Кононко О. Л. Психологічні основи особистісного становлення дошкільника (системний підхід) : монографія. Київ: Стилос, 2000.

10. Крутій К. Освітній простір дошкільного навчального закладу : монографія: у 2-х ч. Київ : Освіта. 2009. Ч. 1.

11. Леонтьев О. М. Деятельность, сознание, личность. Москва : Наука, 1975.

12. Петько Л. В. Державний стандарт початкової освіти у ракурсі формування соціальної активності дитини. Наукові записки Бердянського державного педагогічного yн-mу. Серія : Педагогіка : зб. наук. праць. - Бердянськ : БДПУ, 2018. Вип. 1. С. 92-97.

13. Петько Л. В. Особистість. Соціум. Навчальне середовище / Л.В. Петько // Гуманітарний вісник ДВНЗ «Переяслав-Хмельницький державний педагогічний університет імені Григорія Сковороди»: збірник наукових праць. Вип. 35. ПереяславХмельницький, 2014. С. 102-110. 
14. Петько Л. В. Підготовка майбутніх педагогів-вихователів до навчання іноземної мови дітей в дошкільних освітніх закладах. Вісник Інституту розвитку дитини. Вип. 23. Серія: Філософія, педагогіка, психологія: зб. наук. праць. Київ : Видво НПУ імені М.П.Драгоманова, 2012. С. 111-115.

15. Піроженко Т. О. Ігрова діяльність дошкільника: навчально-методичний посібник. Київ : Генеза, 2013.

16. Поніманська Т. Готовність до педагогічних інновацій у контексті гуманістичної педагогіки. Оновлення змісту і методів дошкільної освіти в Украӥні. 1999. Вип. 5. Рівне : РДПІ. С. 10-15.

17. Рубинштейн С. Л. Основы общей психологии: в 2-х т. Москва : Педагогика.

18. Слюсаренко Н., Кульбацька М. Суб'єкт-суб'єктний підхід до організації педагогічного процесу. Людинознавчі студіï. Педагогіка. 2015. № 1 (33). С. 194-201.

19. Становлення внутрішньої картини світу дошкільника: монографія / [Т.О. Піроженко, С.О. Ладивір, О.О. Вовчик-Блакитна та ін.]; за ред. Т.О. Піроженко. Кіровоград : Імекс-ЛТД. URI : http://lib.iitta.gov.ua/1604/

20. Эльконин Д.Б. Детская психология. Москва : Педагогика, 1960.

21. Якиманская И. Разработка технологии личностно ориентированного обучения Вопросы психологии. 1995. № 2. С. 37-38.

22. Matviienko O. Pedagogy of partnership in the process of setting new Ukrainian school // Challenges and opportunities of scientific thought development : collection of scientific articles. - GPG Publishing Group, Pretoria, South Africa, 2017. P. 151-156.

23. Matviienko Olena. Theoretical Basics of Preparation of Teachers to Pedagogical Interaction with Children of Various Age. Intellectual Archive. 2014. Volume 5. No. 5 (September). Toronto : Shiny Word Corp., Canada. Pp. 105-117. 